\title{
Population and reproductive traits of a freshwater amphipod (Crustacea, Peracarida, Hyalellidae) from northwest of the state of Rio Grande do Sul, Brazil
}

\author{
Daniela da Silva Castiglioni $^{1}{ }^{\circledR}$, Marcio Limberger $^{I}$, Vanessa da Silva Castro ${ }^{I}$ \& Francieli Ubessi ${ }^{I}$ \\ ${ }^{1}$ Universidade Federal de Santa Maria, Campus de Palmeira das Missões, Laboratório de Zoologia e \\ Ecologia, Av. Independência, 3751, 983000-000, Palmeira das Missões, RS, Brasil. \\ *Corresponding author: Daniela da Silva Castiglioni, e-mail: danielacastiglioni@yahoo.com.br
}

\begin{abstract}
CASTIGLIONI, D.S., LIMBERGER, M., CASTRO, V.S., UBESSI, F. Population and reproductive traits of a freshwater amphipod (Crustacea, Peracarida, Hyalellidae) from northwest of the state of Rio Grande do Sul, Brazil. Biota Neotropica 20(2): e20199872. https://doi.org/10.1590/1676-0611-BN-2019-0872
\end{abstract}

\begin{abstract}
The study of population and reproductive traits provides information about the ecological structure of natural populations. This study aimed to characterize dynamics and reproductive traits of Hyalella palmeirensis from a natural pond from southern Brazil. The amphipods were sampled monthly (August 2012 to July 2013) by a person with the aid of a hand net for 20 minutes. Ovigerous females and pre-copulatory pairs were individualized in the field. A total of 12,325 individuals were sampled, being 1,421 males, 6,983 females (including 215 ovigerous females) and 3,921 juveniles. Paired and unpaired males were significantly greater in size than females. There was a positive correlation between body size (CL) of paired males and females. Males and females showed bimodal distribution. Total sex ratio favored females, and these were more frequent in almost all months. Ovigerous females and precopulatory pairs were found throughout the year, but with high frequency in winter and autumn, respectively, characterizing a seasonal reproduction. Juveniles were sampled throughout the year, with greater intensity in the spring. The mean fecundity was $19.6 \pm 4.34$ eggs. No reduction in the number of eggs was observed during embryonic development. The results observed in H. palmeirensis demonstrate that this species has a population and reproductive dynamics very similar to other species of Hyalella already analyzed in southern Brazil. Moreover, it can be seen that although the H. palmeirensis occurs in an environment with anthropic influence (soy cultivation,) the population is managing to remain in the area, with reproduction and recruitment in most months of year.
\end{abstract}

Keywords: fecundity, body size, Hyalella palmeirensis, sex ratio, reproduction, recruitment.

\section{Características populacionais e reprodutivas de um anfípodo de água doce (Crustacea, Peracarida, Hyalellidae) do noroeste do estado do Rio Grande do Sul, Brasil}

Resumo: O estudo dos aspectos populacionais e reprodutivos providenciam informações sobre a estrutura ecológica das populações naturais. Este estudo teve como objetivo caracterizar aspectos populacionais e reprodutivos de Hyalella palmeirensis de uma lagoa do sul do Brasil. Os anfípodos foram amostrados mensalmente (agosto/2012 a julho/2013) por uma pessoa com o auxílio de puçá por 20 minutos. Fêmeas ovígeras e casais em comportamento pré-copulatório foram individualizados no campo. Um total de 12.325 indivíduos foram amostrados, sendo 1.421 machos, 6.983 fêmeas (incluindo 215 fêmeas ovígeras) e 3.921 juvenis. Machos pareados e não pareados são significativamente maiores em tamanho do que as fêmeas. Houve uma correlação positiva entre o tamanho do corpo (CC) de machos e fêmeas pareados. Machos e fêmeas apresentaram distribuição bimodal. A proporção sexual total favoreceu as fêmeas, e estas foram mais frequentes em quase todos os meses. Fêmeas ovígeras e casais em pré-cópula foram amostrados ao longo do ano, mas com elevada frequência no inverno e outono, respectivamente, caracterizando uma reprodução sazonal. Os juvenis foram amostrados ao longo do ano, com maior intensidade na primavera. A fecundidade média foi de 19,6 \pm 4,34 ovos. Não houve redução no número de ovos durante o desenvolvimento embrionário. Os resultados observados em H. palmeirensis demonstram que esta espécie possui uma dinâmica populacional e reprodutiva muito similar a outras espécies de Hyalella já analisadas no sul do Brasil. Além disto, apesar de H. palmeirensis ocorrer num ambiente com influência antrópica (cultivo de soja), sua população está conseguindo se manter na área, com reprodução e recrutamento na maioria dos meses do ano. Palavras-chave: fecundidade, tamanho corpóreo, Hyalella palmeirensis, razão sexual, reprodução, recrutamento. 


\section{Introdution}

The freshwater amphipods of the genus Hyalella, Smith, 1874 inhabit a wide variety of aquatic environments of the Americas, as streams, lakes, rivers and some species are found in subterranean environments (Bousfield 1996; González \& Watling, 2002; Bueno et al. 2014; Cardoso et al. 2014; Rodrigues et al. 2017). These crustaceans and have a great ecological importance, since they provide and facilitate the matter and energy transfer between trophic levels, convert detritus into the final particulate organic matter and serve as food for many waterfowl, macroinvertebrates, fish, amphibians, birds (Swanson 1984; Wen 1992; Wellborn 2002; Wellborn \& Cothran 2007). Besides, Hyalella are crustaceans most commonly used as freshwater quality bioindicators and test organisms in ecotoxicological studies in mainly due to their high sensitivity to contaminants and environments impacts (Morris et al. 2003; Wilcoxen et al. 2003; Gust 2006; Ding et al. 2011; Lasier \& Urich 2014; Javidmehr et al. 2015).

Ecological studies of the Hyalella genus in South America are mainly focused on the abundance, body size, sex ratio, reproduction, fecundity, recruitment and, pairing success (Lopretto 1983; Casset et al. 2001; Poretti et al. 2003; Galassi et al. 2006; Castiglioni \& BondBuckup 2007, 2008a, 2008b, 2009; Castiglioni et al. 2007; Torres et al. 2015; Bastos-Pereira \& Bueno 2016a, 2016b; Castiglioni et al. 2016; Ozga \& Castiglioni 2017; Ozga et al. 2018; Colla \& César 2019). The knowledge of these ecological traits of its populations are crucial for long-term conservation plans, the evaluation of its extinction risk as well as its potential use as bioindicators in ecotoxicological studies (Cooper 1965; Hutchinson 1981; Muskó 1992; Castiglioni et al. 2016).

In the South America, Brazil has the greatest number of Hyalella species described, 28 in total (Bastos-Pereira \& Bueno 2013; Bueno et al. 2014; Cardoso et al. 2014; Rodrigues et al. 2014; Streck et al. 2017; Bastos-Pereira et al. 2018; Streck-Marx \& Castiglioni 2020). According to Bueno et al. (2014), Streck et al. (2017) and Streck-Marx $\&$ Castiglioni (2020), the state of Rio Grande do Sul (Southern Brazil) is the region with the highest species diversity in the country, counting 12 described species. Among the species that occur in Brazil, Hyalella palmeirensis Streck-Marx \& Castiglioni, 2019 was recently described (Streck-Marx \& Castiglioni 2020), but its biology and ecology are unknown. Thus, this study aimed to characterize the population and reproductive traits of the freshwater amphipod $H$. palmeirensis from southern Brazil, and for this the abundance, body size, frequency distribution, body size, sexual maturity, sex ratio, reproductive period, fecundity and recruitment were analyzed.

\section{Material and Methods}

The specimens of $H$. palmeirensis were sampled monthly from August 2012 to July 2013 in a natural pond (Figure 1A) by a person with the aid of a hand net (mesh of $250 \mu \mathrm{m}$ ) for 20 minutes. The natural pond is located in the municipality of Palmeira das Missões (2756' $57.30^{\prime}$ S - 53 $3^{\circ} 19^{\prime} 35.46^{\prime}$ W), state of Rio Grande do Sul, Brazil. The natural pond is located in a rural property where soybeans, wheat and oats are grown throughout the year (Figure 1B), and is surrounded by a narrow strip of native shrubs and has macrophytes of the genus Egeria.

During the sampling period, the sediment and macrophytes were removed of the natural pond with a hand net and placed on plastic trays for separation of ovigerous females (females carrying eggs or juveniles inside
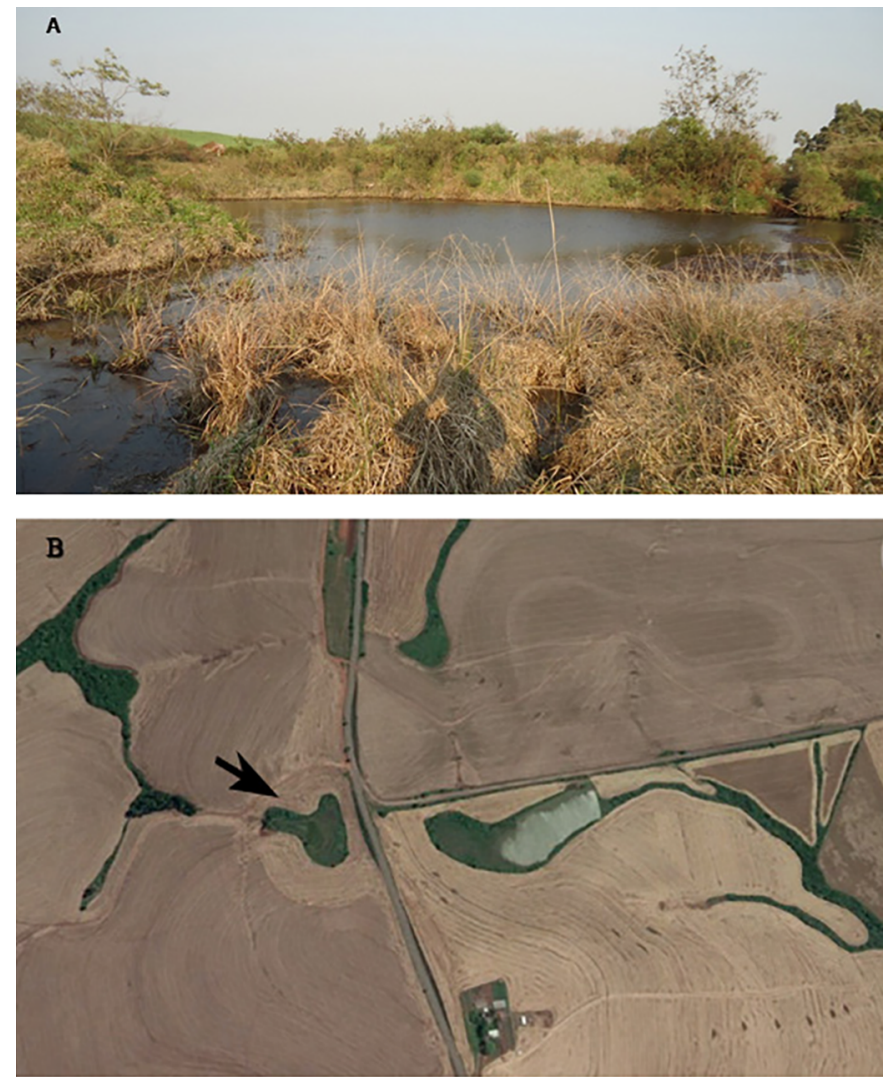

Figure 1. A. Pond where specimens of Hyalella palmeirensis were sampled, municipality of Palmeira das Missões, state of Rio Grande do Sul, Brazil. B. Overview of the pond, showing the crops in its surroundings. The arrow indicates the location where $H$. palmeirensis were sampled.

the brood pouch) and pre-copula pairs. These amphipods were preserved in $70 \%$ ethanol in microtubes. The sediment and macrophytes contained in the plastic trays were placed in plastic bags, transported in a refrigerated container and, in the laboratory, washed in a $0.177 \mathrm{~mm}$ mesh to obtain the remaining organisms that were subsequently preserved in $70 \%$ ethanol.

Later, individuals were identified and grouped into four categories: juveniles (specimens with undeveloped secondary sexual character), males (individuals with a well-developed gnathopod 2), females (individuals with oostegites and a small gnathopod 2), and ovigerous females (females carrying eggs or juveniles in the brood pouch) (Borowsky 1991; Castiglioni $\&$ Bond-Buckup 2008a; Castiglioni et al. 2016). These amphipods were measured from the anterior margin of the rostrum until the posterior margin of the cephalothorax (head), in lateral view (cephalothorax length, CL in $\mathrm{mm}$ ) using a micrometer eyepiece in a stereoscopic microscope.

The total and monthly abundances of juveniles, males, females and ovigerous females were estimated.

The minimum, maximum and mean CL values of males and females (including ovigerous females and non-ovigerous females) and ovigerous females were evaluated. The mean sizes are given with their standard deviations. The mean size was compared between sexes using the $t$ test $(\alpha=0.05$; Zar 1996). Moreover, the mean body size of paired and unpaired males and females were compared, to assess whether pairing success was influenced by body size ( $t$ test; $\alpha=0.05$; Zar 1996).

The sexual maturity of $H$. palmeirensis was estimated through two methods - based on the CL of the smallest ovigerous female found in the population and based on the CL of the smallest male and female 
found in precopulatory behavior (Borowsky 1991; Wellborn et al. 2005; Castiglioni \& Bond-Buckup 2008a; Ozga \& Castiglioni 2017).

Total frequency distribution in size classes (CL) of juveniles, males and females (including ovigerous females) was estimated. The width of the size classes was calculated using the value of $1 / 4$ of the standard deviation from the values of cephalothorax length (Markus 1971). Later, the normality of the frequency distributions was analyzed using Shapiro-Wilk test ( $\alpha=0.05)$ (Zar 1996).

The total, monthly, seasonal, and size-class (CL) sex proportions were expressed as the total number of males divided by the total number of females (including the ovigerous females). The goodness of fit test (chi-Square test $-\chi^{2}$ ) with a significance level of 5\% was used to verify if the sex ratio followed the 1:1 ratio (Zar 1996).

The reproductive period was estimated by seasonal frequency of ovigerous females and pre-copula pairs. The seasonal frequency of ovigerous females in relation to that of adult females (females that were as large as or larger than smallest female found in pre-copula pairs - i.e. estimated size at sexual maturity) was calculated. Later, the ovigerous females proportion was compared among seasons using the multinomial proportions test (MANAP; $\alpha=0.05$ ) (Curi \& Moraes 1981). In addition, the relative frequency of pairs in precopulatory behavior per season was estimated and compared using the multinomial proportion test (MANAP; $\alpha=0.05$ ) (Curi \& Moraes 1981).

In order to verify if males and females choose mating pairs according to their size, the correlation between CL of paired males and females was estimated with a Person correlation $(r)(\alpha=0.05$; Zar 1996).

Ovigerous females were individualized in field to estimate fecundity. In the laboratory, eggs and/or juveniles were removed from the brood pouch of each female and classified according to the stage of embryonic development: 1) initial stage - egg completely filled with yolk, no visible embryonic formation; 2) intermediate stage - initial decrease of yolk, start of embryonic development; 3) final stage - yolk completely consumed by the embryo, which is visible; the eyes are present; 4) juvenile stage - the juveniles hatched and are visible inside the brood pouch (Subida et al. 2005; Castiglioni \& Bond-Buckup 2009; Ozga \& Castiglioni 2017). Later, eggs and juveniles were counted under the stereomicroscope.
The total fecundity of $H$. palmeirensis was estimated (minimum, maximum, and mean \pm standard deviation), as well as the numbers of eggs and juveniles per embryonic stage. Additionally, the fecundity index (FI) was estimated (number of eggs/cephalothorax length). To compare fecundity between the embryonic stages and between seasons, the analysis of variance (ANOVA) was used, followed by the Tukey test $(\alpha=0.05)$ (Zar 1996). Besides, the mean body size (CL) of ovigerous females containing egg in each embryonic development stage or juveniles in the brood pouch was compared by analysis of variance (ANOVA), followed by the Tukey test $(\alpha=0.05)$ (Zar 1996). The relationship between ovigerous females CL $(x)$ and the number of eggs per embryonic stage and number of juveniles $(y)$ was estimated through a regression analysis $(y=a x-b)$ and a Pearson correlation $(r)$ was calculated for each embryonic stage and for the total egg production (considering all stages) $(\alpha=0.05)$ (Zar 1996).

To estimate the recruitment period was calculated the juvenile proportion in relation to adults for each season and we used a goodness of fit test (chi-Square test $\left.-\chi^{2}\right)(\alpha=0.05)$ in order to verify if the proportion follows the pattern 1:1 ratio (juveniles: adults). Besides, the seasonal juvenile frequency was compared using the multinomial proportion test (MANAP; $\alpha=0.05$ ) (Curi \& Moraes 1981). For the recruitment analysis, we considered juveniles those individuals with CL smaller than $0.27 \mathrm{~mm}$ (individuals where the enlargement of the second pair of gnathopods or oostegites could not be observed (Borowsky 1991; Castiglioni et al. 2016) and those individuals smaller than the values estimated at sexual maturity (see values in results).

\section{Results}

During the sampling period, 12,325 individuals were collected, being 1,421 males, 6,983 females (including 215 ovigerous females) and 3,921 juveniles. In the Table I are present the number of males, females, ovigerous females and juveniles sampled by month. The population of $H$. palmeirensis showed the highest abundances in November and January. The lowest abundances were recorded in May and June (Table 1).

Table 1. Number of specimens sampled monthly for a year, monthly sex ratio and goodness of fit analysis $\left(\chi^{2}\right)$ of Hyalella palmeirensis, Palmeira das Missões, state of Rio Grande do Sul, Brazil.

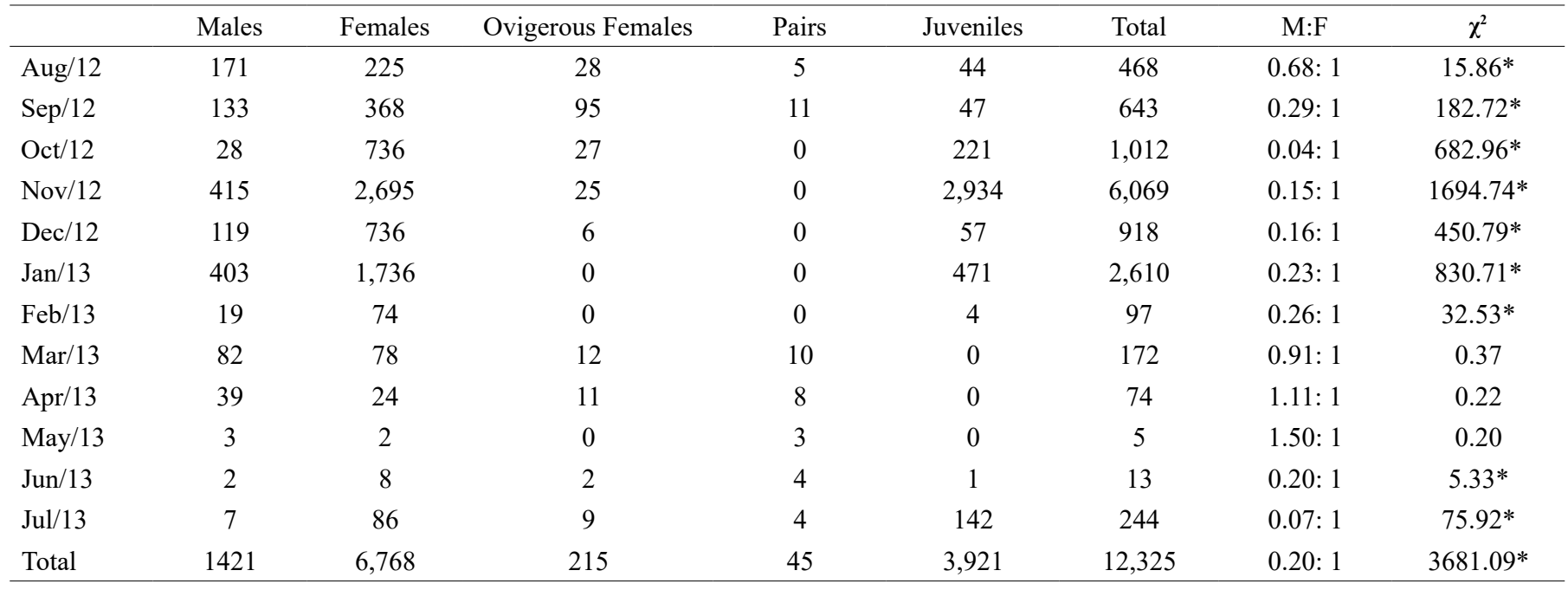

Note: The $" *$ " indicates a significant difference in the proportion of males and females $(\mathrm{p}<0.05)$. 
Castiglioni D.S. et al.

The cephalothorax length of males ranged from 0.27 to $0.74 \mathrm{~mm}$ and that of females from 0.27 to $0.72 \mathrm{~mm}$. The mean CL of unpaired and paired males and females are show in Table 2. Unpaired and paired males were larger than their respective females ( $t=16.77$ for unpaired and $t$ $=8.14$ for paired; $\mathrm{p}<0.05$ ). The mean CL of paired males was greater than that of unpaired males ( $t=15.80 ; \mathrm{p}<0.05$; Table 2$)$. Besides, the mean CL of paired females was greater than that of unpaired females $(\mathrm{t}=8.56 ; \mathrm{p}<0.05$; Table 2$)$. There was a positive correlation between body size $(C L)$ of paired males and females $(r=0.73$; $<<0.05)$.

Table 2. Mean body size (cephalothorax length - CL in $\mathrm{mm}$ ) of unpaired and paired males and females of Hyalella palmeirensis, Palmeira das Missões, state of Rio Grande do Sul, Brazil.

\begin{tabular}{lcc}
\hline & Paired & Unpaired \\
\hline Males & $0.52 \pm 0.0 .5 \mathrm{a}$ & $0.37 \pm 0.10 \mathrm{~b}$ \\
Females & $0.44 \pm 0.04 \mathrm{a}$ & $0.33 \pm 0.08 \mathrm{~b}$ \\
\hline
\end{tabular}

Note: Different lowercase letters indicate significant difference in mena boby size between males and females $(\mathrm{p}<0,05)$.

The size at sexual maturity estimated as the CL of the smallest individual found in pre-copula pairs was 0.45 in males and $0.37 \mathrm{~mm}$ in females. Besides, considering the size of smallest ovigerous female sampled, the size at sexual maturity of females was $0.27 \mathrm{~mm}$.

Size frequency distribution patterns were non-normal in both sexes $(\mathrm{p}<0.05)$ (males $\mathrm{W}=0.86$ and females $\mathrm{W}=0.91)$. Males and females showed bimodal distribution, being divided into two groups (immatures and adults) (Figure 2).

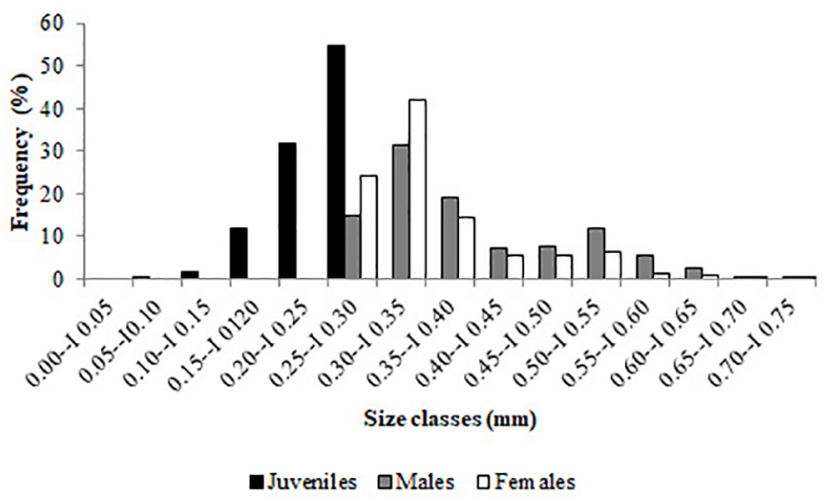

Figure 2 . Frequency distribution in size classes of cephalothorax length (CL in $\mathrm{mm}$ ) for juveniles, males and females of Hyalella palmeirensis, Palmeira das Missões, state of Rio Grande do Sul, Brazil.

The overall male: female sex ratio was $0.20: 1$ and differ significantly from the expected 1:1 proportion $(\chi 2=3681.09$; $p<0.05)$. Sex ratio favored females in most months $(\mathrm{p}<0.05)$, with the exception of March, April and May, in which there was no significant difference in proportion ( $p>0.05$ ) (Table 1). Regarding the sex ratio by size classes, it was observed that proportions favored females in intermediate classes and males in larger classes $(\mathrm{p}<0.05)$ (Figure 3).

Ovigerous females of $H$. palmeirensis were sampled throughout year but was observed greater fluctuations in the abundance (Table 1). In the analysis of the seasonal frequency of ovigerous females, it was observed greater frequency in winter (61.4\%) (Figure 4). The number of

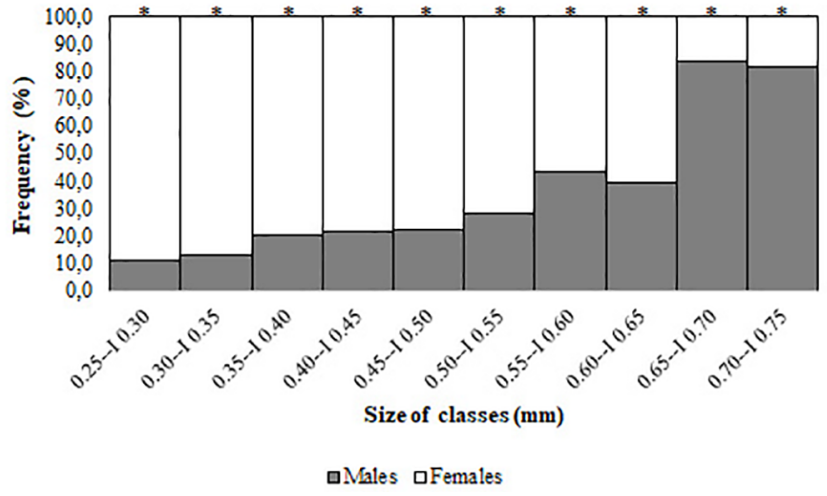

Figure 3. Sex ratio by size classes of cephalothorax length (CL in $\mathrm{mm}$ ) of Hyalella palmeirensis, Palmeira das Missões, state of Rio Grande do Sul, Brazil. "*” indicates significant difference in sex ratio $(\mathrm{p}<0.05)$.

pairs in pre-copulatory behavior was low, when compared to unpaired males and females (Table 1). Pairs in pre-copulatory behavior were found throughout all the year, except spring, being more frequently in autumn (33.3\%) and winter (48.9\%) (Figure 4).

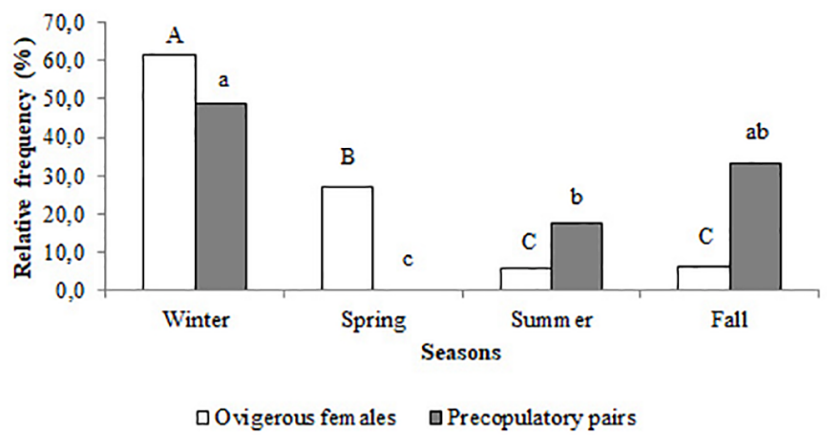

Figure 4. Seasonal relative frequency (\%) of ovigerous females and pairs in pre-copulatory behaviour of Hyalella palmeirensis, Palmeira das Missões, state of Rio Grande do Sul, Brazil. The capital letters represent to the comparison of the frequency of ovigerous females among season and small letters correspond to the comparisons of the frequency of precopulatory pairs. Columns with at least one letter in common did not differ statistically $(\mathrm{p}>0.05)$.

The body size (CL) of ovigerous females ranged from 0.27 to 0.67 $\mathrm{mm}$ (mean \pm standard deviation $-0.48 \pm 0.06 \mathrm{~mm}$ ). Total fecundity varied from 10 to 28 eggs and mean fecundity was $19.6 \pm 4.34$ eggs. The fecundity index (number eggs/cephalothorax length) was $40.43 \pm$ 5.92 eggs. There was a positive correlation between body size (CL) of ovigerous females and egg production $(r=0.79 ; \mathrm{p}<0.05)$ (Figure 5$)$.

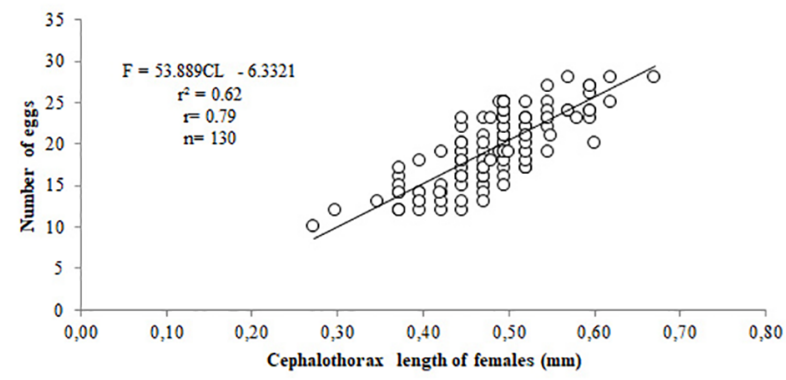

Figure 5. Regression analysis between body size (CL) of ovigerous females and number of eggs produced by Hyalella palmeirensis, Palmeira das Missões, state of Rio Grande do Sul. 
There was no significantly decrease in the number of eggs and juveniles throughout development in H. palmeirensis ( $\mathrm{p}>0.05$ ) (Table 3 ). In addition, there was no difference in mean body size between females containing eggs at each embryonic development stage or juveniles in the brood pouch ( $>0.05$; Table 3 ). Additionally, there was a positive correlation between the body size (CL) of ovigerous females and the number of eggs at each development embryonic stage, and the number of juveniles contained in the brood pouch $(\mathrm{p}<0.05$; Table 3 ). In the analysis of seasonal fecundity, there was also no significant difference in the mean eggs or juvenile's production ( $p>0.05$; Table 4 ).

Juveniles were sampled in all seasons, but the greater relative frequency was observed in spring $(72.7 \%$; $<<0.05)$ and lower in autumn $(0.20 \% ; \mathrm{p}<0.05)$ (Figure 6). The overall juvenile: adult ratio was 4.76:1 and differ significantly from the expected $1: 1$ proportion $(\chi 2=5257.38$; $\mathrm{p}<0.05)$. The ratio of juveniles was superior to the adult ratio in spring $(\chi 2=5809.66 ; \mathrm{p}<0.05)$ and summer $(\chi 2=931.61 ; \mathrm{p}<0.05)$ (Figure 7). However, adults predominated in autumn $(\chi 2=29.39$; $<<0.05)$ and winter $(\chi 2=91.96 ; \mathrm{p}<0.05)$ (Figure 7).

\section{Discussion}

Species of the genus Hyalella can be found mainly along the aquatic vegetation of the banks of streams, lakes, wetlands, springs and underground aquatic environments (Grosso \& Peralta 1999; Bueno et al. 2014). Besides, some species of Hyalella were found associated with macrophytes, which can be used as shelter and/or food by these amphipods (Bueno et al. 2014). In the present study, it was observed that $H$. palmeirensis adheres to macrophyte roots, with abundance peak occurring from spring to summer (October to January), season where there also a high abundance of macrophytes. Colla \& César (2019) reported similar results in H. pampeana where amphipods increased their numbers together with the macrophyte development in warmers months. Aquatic vegetation cover is an important factor influencing invertebrate community structure, presumably because the vegetation creates structural heterogeneity and it can provide refuges and food resources (Hargrave 1970; Waterkeyn et al. 2008). Spring and summer temperatures are ideal for the reproduction of the amphipods, since with the greater food availability, they performed the molt more often, grow and reach the sexual maturity earlier, and shortened the intervals between ovipositions and increased reproductive rate (Cooper 1965; Kruschwitz 1978; Panov \& Mcqueen 1998). In addition, higher temperatures stimulate the production of larger broods and eggs (Siegfried 1985) and increasing juvenile's survival rates
Table 4. Fecundity for the season in Hyalella palmeirensis, Palmeira das Missões, state of Rio Grande do Sul, Brazil.

\begin{tabular}{lcc}
\hline Seasons & Min - max & Mean $\pm \mathrm{sd}$ \\
\hline Summer & $12-25$ & $18.5 \pm 4.27 \mathrm{a}$ \\
Autumn & $12-24$ & $18.3 \pm 4.21 \mathrm{a}$ \\
Winter & $12-28$ & $20.5 \pm 4.01 \mathrm{a}$ \\
Spring & $10-25$ & $18.7 \pm 4.75 \mathrm{a}$ \\
\hline
\end{tabular}

Note: Different lowercase letters indicate significant difference in mean number of eggs $(\mathrm{p}<0,05)$.

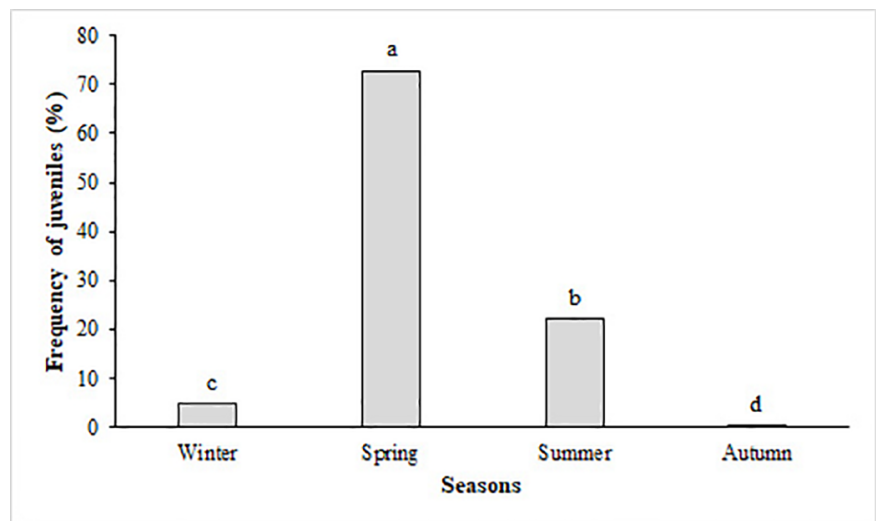

Figure 6. Seasonal relative frequency (\%) of juveniles of Hyalella palmeirensis, Palmeira das Missões, state of Rio Grande do Sul, Brazil. Columns with at least one letter in common did not differ statistically ( $p>0.05$ ).

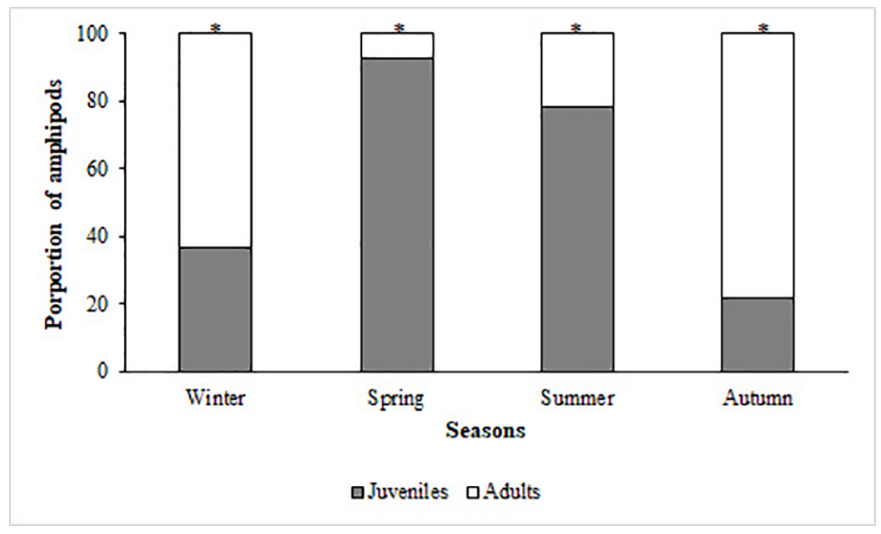

Figure 7. Proportion of juvenile and adults of Hyalella palmeirensis, Palmeira das Missões, state of Rio Grande do Sul, Brazil. “*” indicates significant difference in proportion between juveniles and adults $(\mathrm{p}<0.05)$.

Table 3. Number of eggs and juveniles and minimum, maximum and mean ( \pm SE) cephalothorax length (CL) of the females of Hyalella palmeirensis in different stages of embryonic development and number of juveniles within the brood pouch, Palmeira das Missõe, State of Rio Grande do Sul, Brazil.

\begin{tabular}{|c|c|c|c|c|c|c|}
\hline \multirow{2}{*}{ Development stage } & \multirow{2}{*}{$\mathrm{N}$} & \multicolumn{2}{|c|}{$\mathrm{CL}$ of ovigerous females } & \multicolumn{2}{|c|}{ Eggs } & \multirow{2}{*}{$\mathrm{r}$} \\
\hline & & Min-max & Mean \pm sd & Min-max & Mean \pm sd & \\
\hline Initial & 53 & $0.35-0.67$ & $0.48 \pm 0.06 \mathrm{a}$ & $12-28$ & $19.4 \pm 4.75 \mathrm{a}$ & 0.80 \\
\hline Final & 20 & $0.47-0.62$ & $0.52 \pm 0.05 \mathrm{a}$ & $15-25$ & $18.5 \pm 3.31 \mathrm{a}$ & 0.87 \\
\hline Juvenile & 16 & $0.40-0.52$ & $0.51 \pm 0.04 \mathrm{a}$ & $14-23$ & $18.3 \pm 1.30 \mathrm{a}$ & 0.85 \\
\hline
\end{tabular}

Note: $\mathrm{CL}=$ cephalothorax length; $\mathrm{Min}=$ minimum; $\mathrm{Max}=$ maximum, $\mathrm{r}=$ correlation coefficient. Different lowercase letters indicate significant differences in mean body size (CL) and mean number of eggs. 
(Panov \& Mcqueen 1998). This could explain the high abundances in natural populations of Hyalella during warmer months, as it has been reported by others authors (Casset et al. 2001; Poretti et al. 2003).

Males of $H$. palmeirensis reached sexual maturity at larger sizes and are greater than females. Generally, males reach larger body size than females in freshwater amphipods, as for examples, in $H$. azteca Saussure, 1858 (Pickard \& Benke 1996), H. pleocuta González, BondBuckup \& Araújo, 2006 and H. castroi González, Bond-Buckup \& Araújo, 2006 (Castiglioni \& Bond-Buckup 2008), H. longistila Faxon, 1876 (Bastos-Pereira \& Bueno 2016), H. bonariensis Bond-Buckup, Araujo \& Santos, 2008 (Castiglioni et al. 2016), H. georginae Streck \& Castiglioni, 2017 and H. gauchensis Streck \& Castiglioni, 2017 (Ozga et al. 2018), and H. pampeana Cavalieri, 1968 (Colla \& César 2019). Crustacean growth is similar between sexes until reproductive maturity, and after that, males and females present different ecological and/or reproductive demands resulting in distinct growth rates between sexes (Low 1978). Males invest most of their energy in reproduction, especially in searching for a female and copulation, while in female's energy effort is invested in gamete production and parental care (Wen 1992; Castiglioni \& Bond-Buckup 2007). In addition, females usually grow more slowly due to the prolongation of intermolt period while producing and incubating the embryos, since they do not molt during this period (Hartnoll 1982; Wen 1992; Cardoso \& Veloso 1996). Sexual dimorphism seems essential for crustaceans that have a precopulatory behavior, as Hyalella species (Wen 1992; Castiglioni \& Bond-Buckup 2008; Ozga \& Castiglioni 2017; Castiglioni et al. 2018), because, a large male-to-female size ratio may allow the male carry the female more easily during this phase (Adams \& Greenwood 1983; Adams et al. 1985).

The bimodal frequency distribution of $H$. palmeirensis was marked by the presence of two distinct groups, juveniles and adults. This feature may be related to the seasonal reproduction and, consequently, to the recruitment peaks in the population. This pattern of population frequency distribution is common in other species of Hyalella such as $H$. azteca (Pickard \& Benke 1996), H. pleoacuta and H. castroi (Castiglioni $\&$ Bond-Buckup 2008a), H. bonariensis (Castiglioni et al. 2016) and $H$. georginae and H. gauchensis (Ozga et al. 2018). According to Appadoo \& Myers (2004), bimodal distributions are apparently advantageous since recruitment occurs in warmer months, when food availability is higher, increasing the survival rate.

Females of $H$. palmeirensis are almost 5 times more frequent than males in total and in most months of the year. Sexual deviations in favor of females have already been observed in $H$. pleoacuta and $H$. castroi (Castiglioni \& Bond-Buckup 2008a), H. bonariensis (Castiglioni et al. 2016), H. longistila (Bastos-Pereira \& Bueno 2016), H. georginae and H. gauchensis (Ozga et al. 2018). Deviations in sex ratio appear to be related to reproductive behavior of species of Hyalella, because males spend more time exposed in the environment by choosing, holding and carrying the female and thus the males are more susceptible to predators (Moore 1981; Poweel \& Moore 1991; Wellborn 1994; Wellborn \& Cothran 2007; Kevrekids 2005; Castiglioni \& Bond-Buckup, 2008b; Castiglioni et al., 2016). According to Wellborn (1994) deviations in sex ratio may be due to differential predation by fish and larvae of Odonata, which prefer to feed on larger specimens, such as males, and, therefore, females will be more numerous in the population.

The sex ratio of $H$. palmeirensis favored females in intermediary classes and males in the upper classes, which characterizes an anomalous sex ratio pattern (Wenner 1972). Similar results were found in other species of Hyalella from Brazil (Castiglioni \& Bond-Buckup 2008a; Castiglioni et al. 2016; Bastos-Pereira \& Bueno 2016; Ozga et al. 2018). These results could be related to the same reasons used to explain sexual dimorphisms in relation to body size. The predominance of males in upper size classes which could be related to differences in energy consumption and investment between sexes, being that female's amphipods expend most of their energy and time in reproduction (egg production), while males do so in pairing (Cardoso \& Veloso 1996; Castiglioni \& Bond-Buckup 2007). Besides, the females' prolonged parental behavior, in which they carry the offspring attached to their bodies (Borowski 1991; Thiel 2003; Castiglioni \& Bond-Buckup 2007). Due to this behavior, females direct their energetic budget towards the offspring care instead of molting; therefore, the molt is delayed, limiting the females' body size when in comparison to males (Aoki \& Kikuchi 1991; Thiel 2003).

The reproduction of $H$. palmeirensis occurred more intensely in the colder months of the year, and ovigerous females were more frequent in winter and in pre-copulatory pairs in autumn and winter, indicating a seasonal reproduction. The number of ovigerous females has decreased dramatically in summer and pairs in spring and summer, with this period coinciding with the soybean-growing season around the weir. Probably the use of fertilizers and pesticides may have had a negative effect on $H$. palmeirensis population, causing the mortality of many individuals (see Table 1). It is noteworthy that amphipod species are considered sensitive to pollutants, herbicides and heavy metals, as shown by Kruschwitz (1978), Duan et al. (1997), and Dutra et al. (2008, 2009, 2011). Dutra et al. (2008) observed that carbofuran pesticide induces significant decreases in glycogen, proteins, lipids, triglycerides, and $\mathrm{Na}+/ \mathrm{K}+\mathrm{ATPase}$, as well as a significant increase in lipoperoxidation levels in H. pleoacuta and H. curvispina. Besides, these authors suggested that the reproductive parameters (formation of pre-copulatory pairs, ovigerous females and mean number of eggs) might provide sensitive criteria for assessing ecotoxicological effects. Results similar were observed in $H$. castroi that were exposed to carbofuran at a dose of 5 or 50 microg/L for a period of 7 days (Dutra et al. 2009). Besides, Dutra et al. (2011) observed que concentrations of Roundup ${ }^{\circledR}$ (glyphosate formulation) induced significant decreases in all biochemical parameters and $\mathrm{Na}+\mathrm{K}+\mathrm{ATPase}$ activity, and significant increase in lipoperoxidation levels in $H$. castroi. According to Dutra et al. (2011), very low concentrations of Roundup ${ }^{\circledR}$ have a potentially toxic effect in $H$. castroi and this can lead to significant changes in trophic structure of limnic environments because these amphipods are important links in food chain in these habitats. Dutra et al 2011.

The more intense reproduction in the colder months of the year in H. palmeirensis can be explained by the fact that this time of the year presents a greater abundance of macrophytes on the dam margin (personal observation), and these plants can be used as shelter and food (Castiglioni et al. 2008a; Castiglioni et al. 2016). In addition, the most intense breeding in the colder months should probably be to avoid competition with other spring and summer breeding aquatic invertebrates and thus to ensure the survival of juveniles of Hyalella species. A reproductive peak during the colder months (autumn and/or winter) has been observed in other species of Hyalella found in Brazil (Castiglioni \& Bond -Buckup 2008; Castiglioni et al. 2016; BastosPereira \& Bueno 2016; Ozga et al. 2018). 
Paired males and females were larger than unpaired. Similar results were already recorded for $H$. azteca (Saussure, 1858) (Wen 1992; Wellborn et al. 2005), H. pleoacuta and H. castroi (Castiglioni \& Bond-Buckup 2008b), H. longistila Faxon, 1876 (Bastos-Pereira \& Bueno 2016), H. gauchensis and H. georginae (Ozga \& Castiglioni 2017) and H. bonariensis (Castiglioni et al. 2018). Larger males may be less likely to lose their female during the precopulatory behavior and may be more likely to succeed in attempts to take over a guarded female (Ward 1983; Dick \& Elwood 1990).

The species $H$. palmeirensis exhibited significant positive assortative mating, which was indicated by a correlation between the size of paired males and females, with large males carrying larger females during the precopulatory behavior, and small males carrying small females. This is common among species of Hyalella, such as $H$. pleoacuta and H. castroi (Castiglioni \& Bond-Buckup 2008b), H. longistila (Bastos-Pereira \& Bueno (2016), H. gauchensis and H. georginae (Ozga \& Castiglioni 2017) and $H$. bonariensis (Castiglioni et al. 2018). Several hypotheses proposed by explain the assortative pairing by size in amphipods (Birkhead \& Clarkson 1980; Ward 1984; Elwood et al. 1987; Crespi 1989; Elwood \& Dick 1990; Dick \& Elwood 1996; Ward \& Porter 1993; Cornet et al. 2012; Yu \& Chen 2013). However, the most widely accepted is malemale competition hypothesis (Ward 1983; Elwood et al. 1987; Castiglioni \& Bond-Buckup 2008), which can explain the results observed in $H$. palmeirensis in the present study. According to the male-male competition hypothesis the larger males are better competitors, pairing with larger and more fecund females, because they are better able to affect a takeover, and they are able to resist takeover attempts while in precopulatory behavior (Ward 1983; Ward 1986).

The number of pairs in precopulatory mate-guarding behavior in the population of $H$. palmeirensis was slightly low, when compared to unpaired adults. The same was observed in Hyalella castroi and H. pleoacuta (Castiglioni \& Bond-Buckup 2008b), H. carstica (Torres et al. 2015) and H. bonariensis (Castiglioni et al. 2018). The low occurrence of pairs in this population can be related to the fact that the individuals stay in precopulatory mate-guarding for a short time, approximately 3-4 days (personal observation), since this behavior can make individuals more vulnerable to predation (Strong 1972; Wellborn 1995; Castiglioni \& Bond-Buckup 2008b). Moreover, the sampling procedures may have led to the separation of individuals (Wellborn 1995; Castiglioni \& Bond-Buckup 2008b).

In the present study, it was observed that there is no reduction in the number of eggs during embryonic development in $H$. palmeirensis probably because the number of eggs produced is relatively low and thus there is enough space in the brood pouch for the development of all eggs until the end of embryo incubation, with no loss of embryos. However, there has been a reduction in egg numbers throughout embryonic development in some species of Hyalella from Brazil (Castiglioni \& Bond-Buckup 2009; Bastos-Pereira \& Bueno 2016; Ozga \& Castiglioni 2017; Castiglioni et al. 2018). Usually there is an increase in embryo volume throughout embryonic development and thus the space inside the brood pouch decreases, leading to a premature loss of a few embryos (Koch 1990). In addition, the reduction of eggs/juveniles may be a consequence of the presence of parasites (Sheader 1983; Kuris 1991) or maternal cannibalism, which may occur when food resources are scarce (Sheader 1983; Castiglioni \& Bond-Buckup 2009).

The mean fecundity of $H$. palmeirensis is relatively lower than other species of Hyalella that occur in the state of Rio Grande do Sul, such as H. pleoacuta and H. castroi (Castiglioni \& Bond-Buclup 2009), and H. gauchensis and H. georginae (Ozga \& Castiglioni 2017) and similar to H. bonariensis (Castiglioni et al. 2018). Castiglioni et al. (2018) observed for $H$. bonariensis greater fecundity compared to other Brazilian tropical species, such as $H$. carstica (Torres et al. 2015) and H. longistila (Bastos-Pereira \& Bueno 2016) and one North American species, H. azteca (Othman \& Pascoe 2001; Wellborn et al. 2005). Probably, this difference in fecundity between species of the genus Hyalella may be associated with differences in habitats and microclimate in which species live, a fact already verified by Poweel (1992) and Appadoo \& Myers (2004) for other amphipod species.

In the present study, it was observed that there is no difference in H. palmeirensis fecundity throughout the seasons. On the other hand, Ozga \& Castiglioni (2017) found differences in the number of eggs production for $H$. georginae with lower production in autumn and $H$. gauchensis with lower egg production in spring demonstrating that for these species the environmental conditions were related to reproduction. A reduction in the number of eggs produced in the summer was observed in H. pleocuta and H. castroi (Castiglioni \& Bond-Buckup 2009), in $H$. bonariensis (Castiglioni et al. 2018) and in H. pampeana (Colla \& Cesar 2019). Reduction in the number of eggs in summer may be associated with decreased macrophyte coverage and consequently shelter and food during the warmer months where specimens were sampled suggesting what may be related to a reproductive strategy of this amphipod (Castiglioni \& Bond Buckup 2009; Castiglioni et al.2018). Already results obtained by Torres et al. (2015) for $H$. carstica showed that higher egg production peaked in summer after a long drought period suggesting that females produced more eggs at this time to recover and recolonize the habitat. Differences in seasonal fertility fluctuations observed in these species demonstrate that environmental conditions can directly interfere with reproductive biology as already observed by Maranhão et al. (2001), that cites temperatures and rainfall as factors that may influence the reproduction of amphipods.

The positive correlation between the body size of ovigerous females and the number of eggs in the brood pouch in H. palmeirensis is similar to the results observed for H. azteca (Strong 1972; Othman \& Pascoe 2001), H. pleoacuta e H. castroi (Castiglioni \& Bond-Buckup 2007; Castiglioni \& Bond-Buckup 2009), H. carstica (Torres et al. 2015), H. gauchensis e H. georginae (Ozga et al. 2017), H. bonariensis (Castiglioni et al. 2018) and H. pampeana (Colla \& César 2019). According to Castiglioni \& Bond-Buckup (2009), body size of females may be related to the number of eggs produced, being that larger females are capable of producing more embryos and carry them in the brood pouch during the all embryonic development. Furthermore, in each species the great variability of the body shape can be interfere in the volume available for gonadal development and, consequently, in the brood size (Hines 1988).

The juvenile frequency of $H$. palmeirensis was high in spring and summer due to the peak of reproduction in the colder months of the year. Similar results were observed for other species such as $H$. pleoacuta and H. castroi (Castiglioni \& Bond-Buckup 2008a) where juveniles were sampled in all seasons, being higher than the proportion of adults in most months, but showing frequency peaks in spring. Castiglioni et al. (2018) reported that adults of $H$. bonariensis outnumbered juveniles in the autumn, winter, and summer, showing only that juveniles represented only $25 \%$ of the total population. Juvenile peaks occurred in winter and 
spring. Results observed in this study for H. palmeirensis regarding the high frequency of juveniles compared to adults in the warmer months of the year may be related to a reproductive strategy to ensure species survival as seasonal changes may interfere with food availability and possibly cause mortality (Price 1974; Smith \& Fretwell 1974).

\section{Conclusions}

The results observed in H. palmeirensis demonstrate that this species has a population and reproductive dynamics very similar to other species of Hyalella already analyzed in southern Brazil. Moreover, it can be seen that although the species occurs in an environment with anthropic influence (soy cultivation), the population is managing to remain in the area, with formation of pre-copulatory pairs and release of juveniles in most months of year. Future studies might increase the knowledge about the biology and the relation between population of $H$. palmeirensis and their habitat, as well as their possible use as test in ecotoxicological test.

Moreover, it can be seen that although the $H$. palmeirensis occurs in an environment with anthropic influence (soy cultivation,) the population is managing to remain in the area, with reproduction and recruitment throughout the year.

\section{Acknowledgments}

We thank to Coordenação de Aperfeiçoamento de Pessoal de Nível Superior (CAPES) and Conselho Nacional de Desenvolvimento Científico e Tecnológico (CNPq) for a financial support to the last author (Proc. $n^{\circ} 405061 / 2015-3$ ).

\section{Authors' contributions}

Daniela da Silva Castiglioni: contribution to data collection, concept and design of the study, data analysis and interpretation, and critical revision.

Marcio Limberger: contribution to data analysis and interpretation, and critical revision.

Vanessa da Silva e Castro: contribution to data collection, manuscript preparation, and data analysis.

Francieli Ubessi: contribution to data collection, manuscript preparation, and data analysis.

\section{Conflicts of interest}

There is no conflict of interest.

\section{Ethics}

The sampling was made with authorizations of the Instituto Chico Mendes de Conservação da Biodiversidade (MMA; ICMBio; SISBIO $\left.n^{\circ} 32726-1\right)$.

\section{Data Availability}

The individuals are deposited in the Laboratório de Zoologia e Ecologia, Campus de Palmeira das Missões, Universidade Federal de Santa Maria.

\section{References}

ADAMS, J. \& GREENWOOD, P.J. 1983. Why are males bigger than females in pre-copula pairs of Gammarus pulex? Behav. Ecol. Sociobiol., 13: 239-241.

ADAMS, W.J., KIMERLE, R.A. \& MOSHER, R.G. 1985. Aquatic safety assessment of chemicals sorbed to sediments. In: CARDWELL, R.D., PURDY, R. \& BAHNER, R.C. (ed). Aquatic Toxicology and Hazard Assessment. American Society for Testing and Materials, Philadelphia, pp. $429-453$

AOKI, M. \& KIKUCHI, T. 1991. Two types of maternal care for juveniles observed in Caprella monoceros Mayer, 1890 and Caprella decipiens Mayer, 1890 (Amphipoda: Caprellidae). Hydrobiologia 223: 229-237.

APPADOO, C. \& MYERS, A.A. 2004. Reproductive bionomics and life history traits of three gammaridean amphipods, Cymadusa filosa Savigny, Ampithoe laxipodus Appadoo and Myers and Mallacoota schellenbergi Ledoyer from tropical Indian Ocean (Mauritius). Acta Oecol. 26(3): 227-238.

BASTOS-PEREIRA, R. \& BUENO, A.A.P. 2013. A new species of freshwater amphipod (Dogielinotidae, Hyalella) from Southeastern Brazil. Nauplius 21(1): 79-87.

BASTOS- PEREIRA, R. \& BUENO, A.A.P. 2016 a. Dynamics of a natural population of a hyallelid amphipod from Brazil. J. Crustacean Biol. 36(2): 154-162.

BASTOS- PEREIRA, R. \& BUENO, A.A.P. 2016 b. Reproductive biology and egg production of Hyalella longistila (Faxon, 1876) (Amphipoda: Hyalellidae), a freshwater amphipod in southeastern Brazil. J. Crustacean Biol. 36(5): 724-730.

BIRKHEAD, T.R. \& CLARKSON, K. 1980. Mate selection and precopulatory guarding in Gammarus pulex. Z. Tierpsychol. 52: 365-380.

BOROWSKY, B. 1991. Patterns of reproduction of some amphipod crustaceans and insights into the nature of their stimuli. In: Bauer, R.T. \& Martin, W. (ed.). Journal of Crustacean Sexual Biology 180(10): 33-39.

BOSCHI, R., OLIVEIRA, S.R.M. \& ASSAD, E.D. 2011. Técnicas de mineração de dados para análise da precipitação pluvial decenal no Rio Grande do Sul. Eng. Agríc. 31(6): 1189-1201.

BOUSFIELD, E.L. 1996. A contribution to the reclassification of Neotropical freshwater hyalellid amphipods (Crustacea: Gammaridea, Talitroidea). Boll. Mus. Civico Storia Nat. Verona 20: 175-224.

BUENO, A.A.P., ARAUJO, P.B., CARDOSO, G.M., GOMES, K.M. \& BOND-BUCKUP, G. 2013. Two new species of Hyaella (Amphipoda, Dogielinotidae) from Brazil. Crustaceana 86(7-8): 802-819.

BUENO, A.A.P., RODRIGUES, S.G. \& ARAUJO, P.B. 2014. O estado da arte do gênero Hyalella Smith, 1874 (Crustacea, Amphipoda, Senticaudata, Hyalellidae) no Brasil. In: HAYASHI, C. (ed.). Tópicos de Atualização em Ciências Aquáticas. UFTM, Uberaba 1: 57-88.

CARDOSO, G.M., ARAUJO, P.B., BUENO, A.A.P. \& FERREIRA, R.L. 2014. Two new subterranean species of Hyalella Smith, 1874 (Crustacea: Amphipoda: Hyalellidae) from Brazil. Zootaxa 3814(3): 253-348.

CARDOSO, R.S. \& VELOSO, V.G. 1996. Population biology and secondary production of the sandhopper Pseudorchestoidea brasiliensis (Amphipoda: Talitridae) at Prainha Beach, Brazil. Mar. Ecol. Prog. Ser. 142(1-3): 111-119.

CASSET, M.A., MOMO, F.R. \& GIORGIO, A.D.N. 2011. Dinámica poblacional de dos especies de anfipodos y su relación con la vegetación acuática en un microambiente de la Cuenca del río Luján, Argentina. Ecol. Austral 11: 79-85.

CASTIGLIONI, D.S., GARCIA-SCHROEDER, D., BARCELOS, D.F. \& BOND-BUCKUP, G. Intermolt duration and postembryonic growth of two sympatric species of Hyalella (Amphipoda: Dogielinotidae) in laboratory conditions. Nauplius 15(2): 57-64.

CASTIGLIONI, D.S., STRECK, M.T., RODRIGUES, S.G. \& BUENO, A.A.P. 2018. Reproductive strategies of a population of a freshwater amphipod (Crustacea, Amphipoda, Hyalellildae) from southern Brazil. Biota Neotrop. 18(2): e20170470

CASTIGLIONI, D.S. \& BOND-BUCKUP, G. 2007. Reproductive strategies of two sympatric species of Hyalella Smith, 1874 (Amphipoda, Dogielinotidae) in laboratory conditions. J. Nat. Hist. 41(25-28): 1571-1584. 
CASTIGLIONI, D.S. \& BOND-BUCKUP, G. 2008a. Ecological traits of two sympatric species of Hyalella Smith, 1874 (Crustacea, Amphipoda, Doglielinotidae) from southern Brazil. Acta Oecol. 33(1): 36-48.

CASTIGLIONI, D.S. \& BOND-BUCKUP, G. 2008b. Pairing and reproductive success in two sympatric species of Hyalella (Crustacea, Amphipoda, Doglielinotidae) from southern Brazil. Acta Oecol. 33(1): 49-55.

CASTIGLIONI, D.S. \& BOND-BUCKUP, G. 2009. Egg production of two sympatric species of Hyalella Smith, 1874 (Crustacea, Amphipoda, Dogielinotidae) in aquaculture ponds in southern Brazil. J. Nat. Hist. 43(21-24):1273-1289.

CASTIGLIONI, D.S., OZGA, A.V., RODRIGUES, S.G. \& BUENO, A.A.P. 2016. Population dynamics of a freshwater amphipod from South America (Crustacea, Amphipoda, Hyalellidae). Nauplius 24: 1-9.

COLLA, M.F. \& CÉSAR, I.I. 2019. Ecological aspects of a natural population of Hyalella pampeana (Crustacea, Amphipoda, Hyalellidae) from the Natural Reserve Island of Martín García (Río de La Plata, Argentina). An. Acad. Bras. Ciênc. 91(1): e20170928.

COLLA, M.F. \& CÉSAR, I.I. 2015. A new species of Hyalella (Crustacea, Amphipoda, Dogielinotidae) from the Atlantic Forest of Missiones, Argentina. Zookeys 481: 25-38.

COOPER, W.E. 1965. Dynamics and production of a natural population of a freshwater amphipod Hyalella azteca. Ecol. Monogr. 35(4): 377-394.

CORNET, S., LUQUET, G. \& BOLLACHE, L. 2012. Influence of female moulting status on pairing decisions and size-assortative mating in amphipods. J. Zool. 286(4): 312-319.

CRESPI, B.J. 1989. Causes of assortative mating in arthropods. Anim. Behav. 38: $980-1000$.

CURI, P.R. \& MORAES, R.V. 1981. Associação, homogeneidade e contrastes entre proporções em tabelas contendo distribuições multinomiais. Cienc. Cult. 33(5): 712-722.

DICK, J.T.A. \& ELWOOD, R.W. 1990. Symmetrical assessment of females quality by male Gammarus pulex (Amphipoda) during struggles over precopula females. Anim. Behav. 40: 877-883.

DICK, J.T.A. \& ELWOOD, R.W. 1996. Effects of natural variation in sex ratio and habitat structure on mate-guarding decisions in amphipods (Crustacea). Behaviour 133: 985-996.

DING, Y., WESTON, D.P., YOU, J., ROTHERT, A.K. \& LYDY, M.J. 2011 Toxicity of sediment-associated pesticides to Chironomus dilutus and Hyalella azteca. Arch. Environ. Contam. Toxicol. 61(1): 83-92.

DUAN, Y., GUTTMA, S.I. \& ORIS, J.T. 1997. Genetic differentiation among laboratory populations of Hyalella azteca: implications for toxicology. Environ. Toxicol. Chem. 16(4): 691-695.

DUTRA, B.K., FERNANDES, F.A., FAILACE, D.M. \& OLIVEIRA, G.T. 2011. Effect of roundup (glyphosate formulation) in the energy metabolism and reproductive traits of Hyalella castroi (Crustacea, Amphipoda, Dogielinotidae). Ecotoxicology 20: 255-263.

DUTRA, B.K., FERNANDES, F.A. \& OLIVEIRA, G.T. 2008. Carbofuraninduced alterations in biochemical composition, lipoperoxidation, and $\mathrm{Na}^{+} / \mathrm{K}^{+}$ATPase activity of Hyalella pleoacuta and Hyalella curvispina in bioassays. Comp. Biochem. Physiol. C 147:179-188.

DUTRA, B.K., FERNANDES, F.A., LAUFER, A.L. \& OLIVEIRA, G.T. 2009. Carbofuran-induced alterations in biochemical composition, lipoperoxidation, and $\mathrm{Na}^{+} \mathrm{K}^{+}$ATPase activity of Hyalella castroi in bioassays. Comp. Biochem. Physiol. C 149:640-646.

ELWOOD, R.W. \& DICK, J.T.A. 1990. The amorous Gammarus: the relationship between precopula duration and size assortative mating in G. pulex. Anim. Behav. 39, 828-833.

ELWOOD, R.W., GIBSON, J. \& NEIL, S. 1987. The amorous Gammarus: size assortative mating in G. pulex. Anim. Behav. 35: 1-6.

GALASSI, M.E., FRANCESCHINI, M.C. \& NEIFF, A.P. 1996. Population estimates of Hyalella curvispina Shoemaker (Amphipoda) in aquatic vegetation of northeastern Argentinian ponds. Acta Limnol. 18(1): 101-108.

GONZÁLEZ, E.R. \& WATLING, L. 2002. A new species of Hyalella from the Andes in Peru (Crustacea: Hyalellidae). Rev. Biol. Trop. 50(2): 649-658.
GROSSO, L. \& PERALTA, M. 1999. Anfípodos de agua dulce sudamericanos. Revisión del género Hyalella Smith. Acta Zool. Lilloana 45(1): 79-98.

GUST, K.A. 2006. Joint toxicity of cadmium and phenanthrene in the freshwater amphipod Hyalella azteca. Arch. Environ. Com. Tox. 50(1): 7-13.

HARGRAVE, B.T. 1970. The utilization of benthic microflora by Hyalella azteca (Amphipoda). J. Animal Ecol. 39(2): 427-437.

HARTNOLL, R.G. 1982. Growth. In: BLISS, D.E. (ed.). The Biology of Crustacea: embryology, morphology and genetics. Academic Press, New York, $440 \mathrm{pp}$.

HUTCHINSON, G.E. 1981. Introducción a la ecologia de pobliaciones. Editora Blume, Barcelona. 492 pp.

JAVIDMEHR, A., KASS, P.H., DEAVONIC, L.A., CONNON, R.E. \& WERNER, I. 2015. 10-day survival of Hyalella Azteca as a function of water quality parameters. Ecotoxicol. Environ. Saf. 115: 250-256.

KOCH, H. 1990. Aspects of the population biology of Traskorchestia traskiana (Stimpson, 1857) (Amphipoda, Talitridae) in the Pacific Northwest, USA. Crustaceana 59: 35-52.

KRUSCHWITZ, L.G. 1978. Environmental factors controlling reproduction of the amphipod Hyalella Azteca. Proc. Okla. Acad. Sci. 58: 16- 21.

LASIER, P.J. \& URICH, M.L. 2014. A simple control for sediment-toxicity exposures using the amphipod Hyaella azteca. Bull. Environ. Contam. Toxicol. 93: 263-267.

LOPRETTO, E.C. 1983. Contribucíon a la bioecologia del anfípodo dulciacuícola Hyalella pampeana Cavalieri I. Comportamiento reproductivo. Limnobios. 2: $371-378$

LOW, B.S. 1978. Environnmental uncertainty and parental strategies of marsupials and placentals. Am. Nat. 112: 319-335.

MARANHÃO, P., BENGALA, N., PARDAL, M. \& MARQUES, J.C. 2001. The influence of environmental factors on the population dynamics, reproductive biology and productivity of Echinogammarus marinus Leach (Amphipoda, Gammaridae) in the Mondego estuary (Portugal). Acta Oecol. 22(3): 139-152.

MARKUS, R. 1971. Elementos de estatística aplicada. Faculdade de Agronomia e Veterinária da UFRGS: Centro Acadêmico Leopoldo Cortez, Porto Alegre, $329 \mathrm{pp}$.

MOORE, P.G. 1981. The life histories of the amphipods Lembos websteri Bate and Corophium bonnellii Milne Edwards in kelp holdfasts. J. Exp. Mar Biol. Ecol. 49(1): 1-50.

MORRIS, J.M., COLLYARD, S.A. \& MEYER, J.S. 2003. Effects of chronic copper exposure on the nutritional composition of Hyalella azteca. Aquat Toxicol. 63(2): 197-206.

MUSKÓ, I.B. 1993. Life history of Corophium curvispinum G. O. Sars (Crustacea, Amphipoda) living on macrophytes in Lake Balaton. Hydrobiologia 243/244 (1): 197-202.

OTHMAN, M.S. \& PASCOE, D. 2001. Growth, development and reproduction of Hyalella azteca (Saussure, 1858) in laboratory culture. Crustaceana 74(2): 171-181

OZGA, A.V.; CASTRO, V.S. \& CASTIGLIONI, D.S. 2018. Population structure of two freshwater amphipods (Crustacea: Peracarida: Hyalellidae) from southern Brazil. Nauplius 26: e2018025.

OZGA, A.V. \& CASTIGLIONI, D.S. 2017. Reproductive biology of two species of Hyalella Smith, 1874 (Crustacea: Amphipoda: Hyalellidae) from southern Brazil. J. Nat. Hist. (41-42): 2509-2521.

PANOV, V.E. \& MACQUEEN, D.J. 1998. Effects of temperature on individual growth rate and body size of a freshwater amphipod. Can. J. Zool. 76(6): 1107-1116.

PICKARD, D.P. \& BENKE, A.C. 1996. Population dynamics of Hyalella azteca (Amphipoda) among different habitats in a small wetland in the southeastern U.S.A. J. N. Am. Benthol. 15: 537-554.

PORETTI, T.I.; CASSET, M.A. \& MOMO, F. 2003. Composicíon quimica y dinámica poblicional de Hyalella curvispina en el Arroyo Las Flores (Cuenca del Río Luján). Biol. Acuát. 20: 45-48.

POWELL, R. 1992. Biometry of brooding in seven species of amphipods (Crustacea) from the Clyde sea area. J. Nat. Hist. 26: 353-371. 
PRICE, P.W. 1974. Strategies for eggs production. Evolution, 28: 76-84.

RODRIGUES, S.G., BUENO, A.A.P. \& FERREIRA, R.L. 2014. A new troglobiotic species of Hyalella (Crustacea, Amphipoda, Hyalellidae) with a taxonomic key for the Brazilian species. Zootaxa 3815(2): 200-214.

SHEADER, M. 1983. The reproductive biology and ecology of Gammarus duebeni (Crustacea: Amphipoda) in southern England. J. Mar. Biol. Assoc. U.K. 63: 517-540

KURIS, A.M. 1991. A review of patterns and causes of crustacean brood mortality. In Crustacean Issues 7: Crustacean Egg Production (A. WENNER \& A. KURIS, eds) Balkema Academic, Rotterdam, p.117-141.

SIEGFRIED, C.A. 1985. Life history, population dynamics and production of Pontoporeia hoyi (Crustacea, Amphipoda) in relation to the trophic gradient of Lake George, New York. Hydrobiologia 122:175-180

SMITH, C.C. \& FRETWELL, S.D. 1974. The optimal balance between size and number of offspring. Am. Nat. 108: 499-506.

STRECK, M.T. \& CASTIGLIONI, D.S. in press. A new species of freshwater amphipod (Crustacea, Amphipoda, Hyalellidae) from state of Rio Grande do Sul, Southern Brazil. Biota Neotropica.

STRECK, M.T., MONTICELLI, G., RODRIGUES, S.G., GRAICHEN, D.A.S. \& CASTIGLIONI, D.S. 2017. Two new species of Hyalella (Crustacea, Amphipoda, Hyalellidae) from state of Rio Grande do Sul, Southern Brazil. Zootaxa 4337(2): 263-278.

STRONG, Jr. D.R. 1972. Life history variation among populations of an amphipod (Hyalella azteca). Ecology 53(6): 1103-1111.

SUBIDA, M.D., CUNHA, M.R. \& MOREIRA, M.H. 2005. Life history, reproduction, and production of Gammarus chevreuxi (Amphipoda: Gammaridae) in the Ria de Aveiro, northwestern Portugal. J. N. Am. Benthol. 249(1): 82-100.

SWANSON, G.A. 1984. Dissemination of amphipods by waterfowl. J. Wildlife Manage. 48(3): 988-991.

THIEL, M. 2003a. Extended parental care in crustaceans - an update. Rev. Chil. Hist. 76(2): 205-218.

TORRES, S.H.S., BASTOS-PEREIRA, R. \& BUENO, A.A.P. 2015. Reproductive aspects pf Hyalella carstica (Amphipoda: Hyalellidae) in a natural environment in southeastern Brazil. Nauplius 23(2): 159-165.

WARD, P.I. 1983. Advantages and a disavantages of large size for male Gammarus pulex (Crustacea: Amphipoda). Behav. Ecol. Sociobiol. 14(1): 69-76.

WARD, P.I. \& PORTER, A.H. 1993. The relative roles of habitat structure and male-male competition in the mating system of Gammarus pulex (Crustacea, Amphipoda): a simulation study. Anim. Behav. 45: 119-133.

WARD, P.I. 1984. The effects of size on the mating decision of Gammarus pulex (Crustacea: Amphipoda). Z. Tierpsychol. 64: 174-184.
WARD, P.I. 1986. A comparative study of the breeding behaviour of a stream and a pond of Gammarus pulex (Amphipoda). Oikos 46: 29-36.

WATERKEYN,A.; GRILLAS, P.; VANSCHOENWINKEL, B. \& BRENDONCK, L. 2008. Invertebrate community patterns in Mediterranean temporary wetlands along hydroperiod and salinity gradients. Freshwater Biol. 53: 1808-1822.

WELLBORN, G.A. 1994. Size-biased predation and prey life histories: a comparative study of freshwater amphipod populations. Ecology 75: 2104-2117.

WELLBORN, G.A. 1995. Determinants of reproductive success in freshwater amphipod species that experience different mortality regimes. Anim. Behav. 50(2): 353-363.

WELLBORN, G.A. 2002. Trade-off between competitive ability and antipredator adaptation in a freshwater amphipod species complex. Ecology 83(1): 129-136.

WELLBORN, G.A., COTHRAN, R. \& BARTHOLF, S. 2005. Life history and allozyme diversification in regional ecomorphs of the Hyalella azteca (Crustacea: Amphipoda) species complex. Biol. J. Linn. Soc. 84(2): 161-175.

WELLBORN, G.A. \& COTHRAN, R.D. 2007. Niche diversity in crustacean cryptic species: complementarity in spatial distribution and predation risk. Oecologia 154(1): 175-183.

WEN, Y.H. 1992. Life history and production of Hyalella azteca (Crustacea, Amphipoda) in a hypereutrophic prairie pond in southern Alberta. Can. J. Zool. 70: 1417-1424.

WENNER, A.M. 1972. Sex-ratio as a function of size in marine Crustacea. Am. Midl. Nat. 106: 321-350.

WILCOXEN, S.E.; MEIER, P.G. \& LANDRUM, P.F. 2003. The toxicity of fluoranthene to Hyalella azteca in sediment and water-only exposures under varying light spectra. Ecotox. Environ. Safe. 54: 105-117.

YU, T.L. \& CHEN, J.B. 2013. Mating patterns of Gammarus lacustris (Amphipoda: Gammaridae) from three populations across a gradient on the Tibetan Plateau. Ital. J. Zool. 80(4): 608-613

ZAR, J.H. 1996. Biostatistical analysis. Prentice Hall, Upper Saddle River. $941 \mathrm{pp}$. 